\title{
The angel flap for nipple reconstruction
}

\author{
Wendy W Wong MD, Matthew A Hiersche MD, Mark C Martin MD DMD FRCSC
}

\author{
WW Wong, MA Hiersche, MC Martin. The angel \\ flap for nipple reconstruction. Can J Plast Surg \\ 2013;21(1):e1-e4.
}

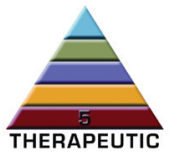

Creation of an aesthetically pleasing nipple plays a significant role in breast reconstruction as a determining factor in patient satisfaction. The goals for nipple reconstruction include minimal donor site morbidity and appropriate, long-lasting projection. Currently, the most popular techniques used are associated with a significant loss of projection postoperatively. Accordingly, the authors introduce the angel flap, which is designed to achieve nipple projection with lasting results. The lateral edges of the flap and the area surrounding the top of the nipple are de-epithelialized and the flaps are wrapped to create a nipple mound composed primarily of dermis. Decreasing the amount of fat within core of the nipple and enhancing dermal content promotes long-lasting projection. Furthermore, the incision pattern fits within a desired areolar size, preventing unnecessary superfluous extension of the incisions. Thus, the technique described herein achieves the goals of nipple reconstruction, including adequate and long-lasting projection, without extension of the lateral limb scars.

Key Words: Angel flap; Breast reconstruction; Dermal flap; Long-lasting projection; Nipple reconstruction

$\Delta \mathrm{s}$ more women undergo breast reconstruction following mastecAtomy, the necessity of excellent nipple-areola reconstruction becomes increasingly relevant. The creation of a pleasing nipple-areola complex is the final stage in breast reconstruction following the recreation of the breast mound. This is an important procedure in recreating a 'breast' that is visually analogous to the preoperative breast. Often, breast reconstruction is an important facet of both physical and psychological healing for women who have been diagnosed with breast cancer. As the final stage in the reconstructive process, it is imperative that the procedure provide a pleasing aesthetic outcome with consistent projection, minimal adjacent tissue distortion and excellent symmetry.

In practice and in the literature, the use of local tissue flaps has become the primary contemporary technique. Local flaps preclude the creation of an additional donor site, minimizing perioperative discomfort and additional comorbidities. While each local flap exhibits its own advantages, certain common limitations are ubiquitous. Paramount among these limitations is the loss of projection seen with all local flap techniques. Objective measures assessing long-term nipple projection in the literature are sparse; however, studies that have evaluated long-term follow-up cite a loss of projection of $40 \%$ or more (Table 1) (1-19). This problem has led many to advocate creating overprojection of the nipple to at least $150 \%$ of the contralateral side to allow for loss of projection. This technique is less than ideal, however, because it increases the necessary local tissue required, creates more potential distortion of the breast mound, places a larger demand on the vascular pedicle that is already susceptible to necrosis and provides an inconsistent result. With regard to projection, reliability and a range of application, a simple and reliable method appropriate for all scenarios remains elusive.

\section{Le lambeau de l'ange pour la reconstruction du mamelon}

La création d'un mamelon agréable sur le plan esthétique est un facteur déterminant de la satisfaction de la patiente qui subit une reconstruction mammaire. La reconstruction du mamelon vise à susciter une morbidité minimale au foyer du prélèvement et une projection pertinente et durable. Les techniques actuelles les plus populaires s'associent à une importante perte de projection après l'opération. C'est pourquoi les auteurs présentent le lambeau de l'ange, conçu pour procurer une projection du mamelon aux résultats durables. Les bordures latérales du lambeau et de la région entourant le dessus du mamelon sont désépithélialisées et les lambeaux sont repliés pour former un monticule mamelonnaire composé surtout de derme. Le fait de réduire la quantité de matière grasse au cœur du mamelon et d'en accroître le contenu dermique favorise une projection durable. De plus, le mode d'incision s'associe à la dimension souhaitée de l'aréole et évite l'extension inutile des incisions. La technique décrite aux présentes permet donc la reconstruction du mamelon, y compris une projection convenable et durable, sans extension des cicatrices latérales sur les membres.

Department of Plastic Surgery, Loma Linda University, Loma Linda, California, USA

Correspondence: Dr Wendy W Wong, Department of Plastic Surgery, Loma Linda University, 11175 Campus Street,

Suite 21126CP, Loma Linda, California 92350, USA. Telephone 909-558-8085, fax 909-558-4175, e-mail wewong@llu.edu 
TABLE 1

Characteristics of the most commonly used flaps for nipple reconstruction

\begin{tabular}{|c|c|c|c|}
\hline Name/type of flap (reference) & $\begin{array}{l}\text { Primary component } \\
\text { of nipple core }\end{array}$ & $\begin{array}{l}\text { Component of } \\
\text { foundation }\end{array}$ & Disadvantages (reference) \\
\hline Quadrapod flap (1) & Fat & Fat & Loss of projection \\
\hline Cutaneous-fat flap (2) & Fat & Fat & Was not described for implant reconstruction \\
\hline T-flap (3) & Fat & Fat & Decrease in nipple projection \\
\hline Dermal-fat flap (4) & Fat & Fat & Required an additional donor site \\
\hline Pinwheel flap (5) & Fat & Fat & Loss of projection \\
\hline Buried dermal hammock (6) & Fat & Dermis & Inadequate projection \\
\hline \multirow[t]{2}{*}{ Skate flap (7) } & Fat & Fat & $40 \%$ loss of projection (8) \\
\hline & & & $75 \%$ loss of projection (9) \\
\hline S-flap (10) & Fat and dermis & Fat & Contraction of nipple projection \\
\hline \multirow[t]{2}{*}{ Double-opposing tab flaps } & Fat & Fat & $66 \%$ loss of projection (11) \\
\hline & & & Inadequate projection (average $=2.43 \mathrm{~mm}$ ) $(12)$ \\
\hline \multirow[t]{3}{*}{ Star flap (13) } & Fat & Fat & Inadequate projection (average = $1.97 \mathrm{~mm}$ ) (12) \\
\hline & & & $\begin{array}{l}77 \% \text { loss of projection with implants, } 64 \% \text { loss of projection with autologous } \\
\text { tissue }\end{array}$ \\
\hline & & & $40 \%$ loss of projection ( 8 ) \\
\hline H-flap (15) & Fat & Fat & Decrease in nipple projection \\
\hline \multirow[t]{2}{*}{ Bell flap (16) } & Fat & Fat & Unreliable vascular supply \\
\hline & & & $70 \%$ loss of projection (8) \\
\hline C-V flap (17) & Fat & Fat & Inadequate projection \\
\hline Arrow flap (18) & Fat & Fat & $51 \%$ loss of projection \\
\hline Dermofat graft with C-V flap (19) & Fat and dermis & Dermis & Unreliable vascular supply \\
\hline
\end{tabular}

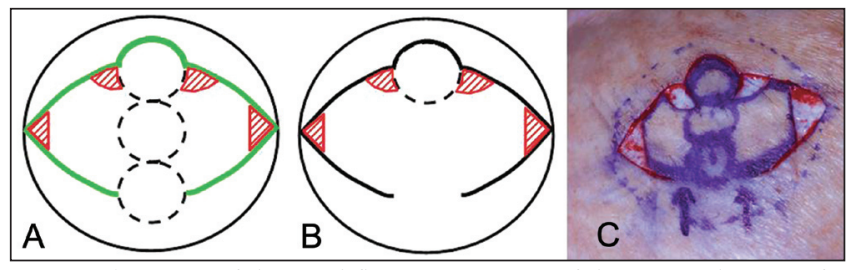

Figure 1) Design of the angel flap. A Depiction of the proposed regions for incised edges of the flap (green) and regions of de-epithelialization (diagonal red stripes). The resulting 'snow angel' appearance of the flap can be clearly seen in B. C Photograph of the same design on a patient's reconstructed breast mound

inferior circles, respectively. Under local anesthesia with $0.5 \%$ lidocaine and epinephrine, the flap is de-epithelialized along the lateral and superior portions as indicated by the four areas of red diagonal stripes as shown in Figure 1A. Subsequently, incisions along the ellipse (marked in green in Figure 1A) are made through the dermis, with care taken to leave an inferiorly based pedicle. Care must be taken to create upper and lower flap edges of equal length. The resulting planned flap has an appearance of a snow angel (Figure 1B). Next, a cutaneous flap underlying the 'wings' and 'head' is elevated with approximately $2 \mathrm{~mm}$ of fat tissue to preserve the subdermal plexus (Figure 2A). The lateral wings are then brought together with the deepithelialized portions conjoining within the nipple centre to form a core of primarily dermis (Figure 2B and 2C). The two de-epithelialized areas adjacent to the planned top of the nipple are tucked, allowing the edges of the nipple top to be approximated to the inferior aspect of the two de-epithelialized edges. The reconstructed nipple is closed with 5-0 chromic sutures while inverting the de-epithelialized tips for support (Figure 2D). The top of the nipple is then laid onto the dermis-filled column and closed onto the repaired wings with 4-0 monocryl sutures.

Steristrips are applied to the transverse incisions and a bolster made of Reston foam (double layer) dressing is applied to the nipple. This bolster not only supports the nipple, but also prevents contraction by avoiding anterior compressive forces from clothing. Patients are

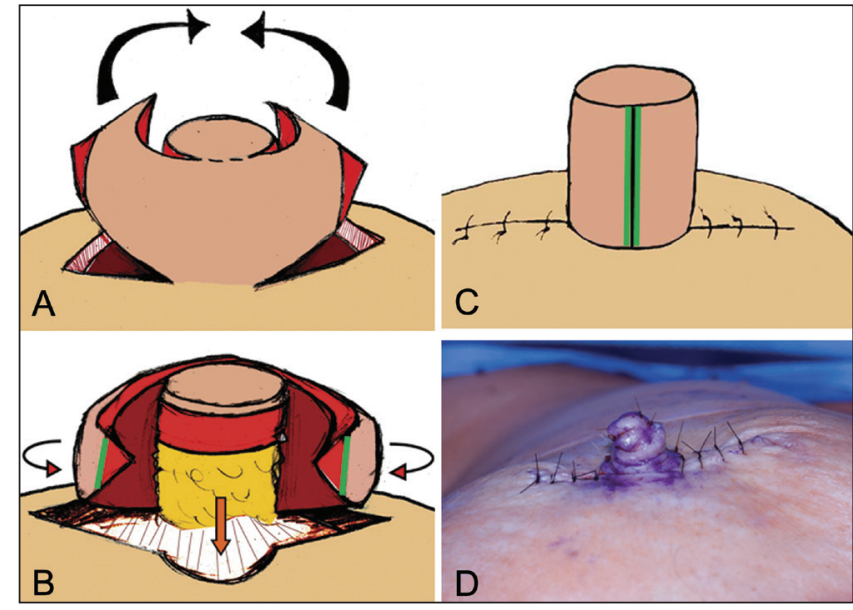

Figure 2) Elevation of the angel flap and formation of nipple. A (inferior view) and B (superior view) demonstrate the direction of how the elevated flap 'wings' are brought together. The de-epithelialized regions are folded into the nipple centre, thereby creating a foundation and core of dermis. The edges of the flap outlined in green in B are brought together as shown in $\mathbf{C}$. $\mathrm{D}$ Demonstrates the immediate postoperative result on a patient

instructed on how to change their gauze at home until their follow-up visit. Approximately eight weeks after this procedure, the appearance of an areola is tattooed around the reconstructed nipple.

\section{DISCUSSION}

Nipple reconstruction has evolved to become an integral part of breast reconstruction and now includes a wide variety of flaps. The resulting appearance of the reconstructed nipple can significantly contribute to a patient's overall satisfaction with the entire breast reconstruction (9). Although many techniques have adequate results, none produce a truly prominent nipple with lasting projection (20). A major problem with local flaps is flattening and subsequent diminished nipple projection, which is believed to be multifactorial in etiology. One of the 


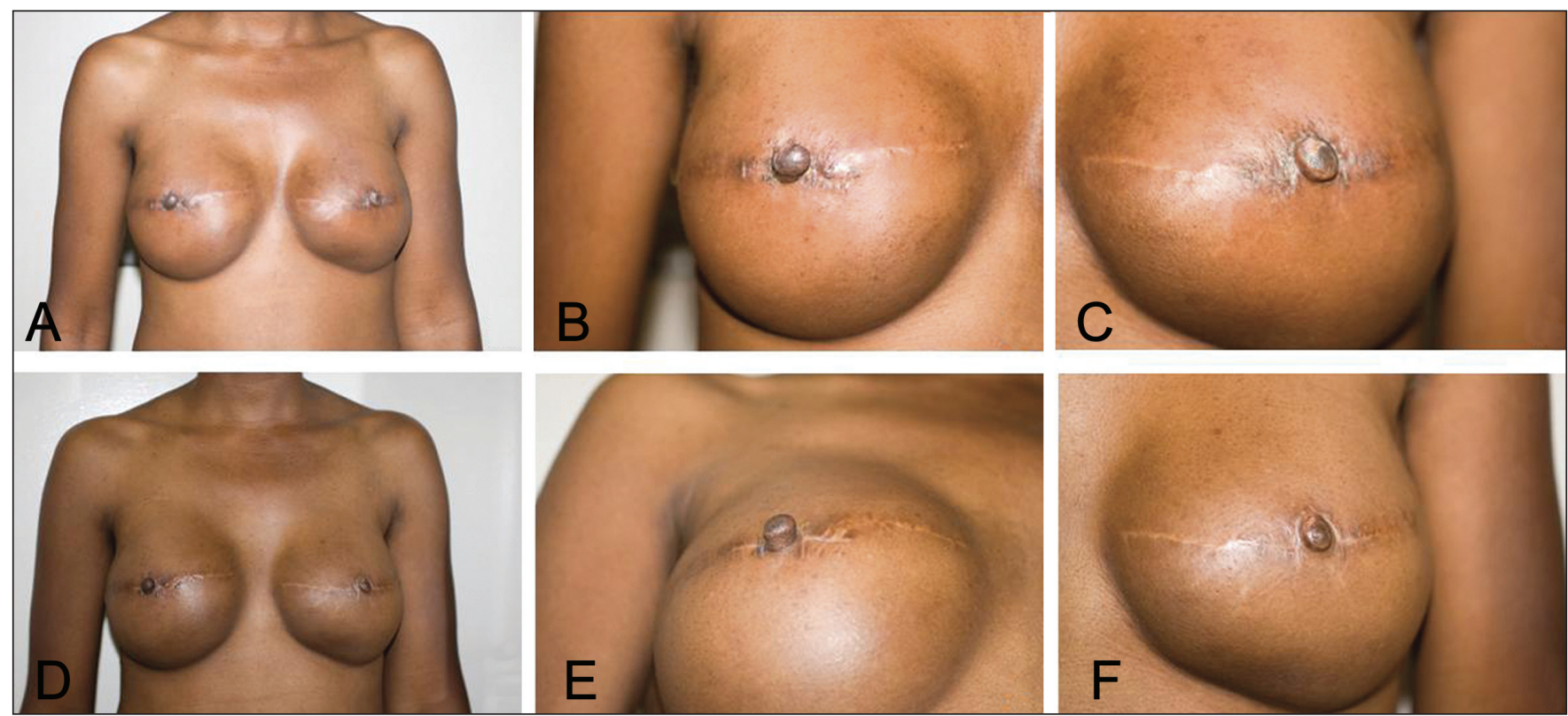

Figure 3) A patient showing typical results of the angel flap technique at four weeks postoperatively (A to C) and at 12 weeks postoperatively (D to F). Good nipple projection is seen with an overall pleasing aesthetic result

primary hypotheses is the concept of centrifugal forces on the breast causing contraction of the nipple-areola complex and subsequent flattening over time. However, the significance of these forces on overall nipple flattening has been debated (21). While centrifugal forces may not contribute to all flattening, they likely contribute to the stress placed on the small dermal lining of the skin flaps. Likewise, loss of local tissue through necrosis or atrophy remains a likely contributor to overall nipple loss. A tenuous blood supply to the supporting elements of the new nipple and a lack of tissue with structural integrity incorporated in the nipple are challenging. As shown in Table 1, all local flaps rely primarily on fat as both the foundation and major structural support of the recreated nipple $(1-7,11,13,15-18)$. These resulting nipples lack dense connective tissue that supports native nipples and can lose projection $(22,23)$. Many techniques have been used to bolster the fat graft or to increase projection, including a buried dermal hammock, cartilage grafts and Alloderm (LifeCell, USA) $(6,24,25)$. However, if the underlying support of the nipple remains as fat, the tissue undergoes necrosis and additional support for that fat becomes inconsequential.

The current practice of using fat as the major component and structural support for nipple reconstruction may explain why flaps have unsuccessfully demonstrated the ability to maintain long-term nipple projection. The pervasive loss of projection has led to a large array of different local flaps without a clear ideal method. The dermal foundation of the angel flap ameliorates this problem compared with other methods' fat as foundation, which eventually lead to nipple contraction into the breast mound. The core of the resulting nipple comprised primarily of dermis and a longer planned nipple height of the flap attribute to long-lasting projection (Figures 3 and 4) and, ultimately, high patient satisfaction. Nipple reconstruction with the angel flap has many additional advantages: the design of the flap is not tenuous; and it has a large base, which enhances vascularity and minimizes the potential of vascular embarrassment in the resulting nipple. Keeping the entire design within the desired areolar circumference prevents the undesirable extension of scars past this margin. Aesthetically, the pleasing shape of the breast mound is preserved, natural appearing nipples are created and primary closure is possible, thus negating the need for a skin graft. Not only is the unpredictable pigmentation of skin grafts avoided, but additional donor sites are unnecessary.

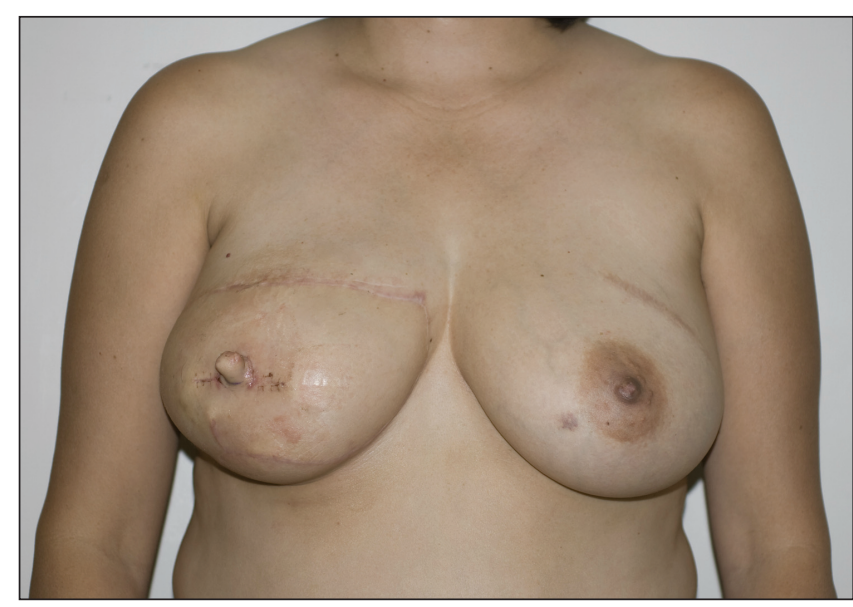

Figure 4) Three-week postoperative photograph of a patinet with good nipple projection following left nipple reconstruction using the angel flap technique

\section{REFERENCES}

1. Little JW III, Munasifi T, McCulloch DT. One-stage reconstruction of a projecting nipple: The quadrapod flap. Plast Reconstr Surg 1983;7:126-33.

2. Bosch G, Ramirez M. Reconstruction of the nipple: A new technique. Plast Reconstr Surg 1984;73:977-81.

3. Chang WH. Nipple reconstruction with a T flap. Plast Reconstr Surg 1984; 73(1):140-143

4. Hartrampf CR Jr. A dermal-fat flap for nipple reconstruction. Plast Reconstr Surg 1984;73:982-6.

5. Cohen IK, Ward JA, Chandrasekhar B. The pinwheel flap nipple and barrier areola graft reconstruction. Plast Reconstr Surg 1986;77:995-9.

6. Mukherjee RP, Gottlieb V, Hacker L. Nipple-areolar reconstruction with the buried dermal hammock technique. Ann Plast Surg 1987;3:43.

7. Little JW. Nipple-areolar reconstruction. Clin Plast Surgery 1984;11:355.

8. Shestak KC, Gabriel A, Landecker A, et al. Assessment of longterm nipple projection: A comparison of three techniques. Plast Reconstr Surg 2002;110:780-6. 
9. Zhong T, Antony A, Cordeiro P. Surgical outcomes and nipple projection using the modified skate flap for nipple-areolar reconstruction in a series of 422 implant reconstructions. Ann Plast Surg 2009;623:591-5.

10. Cronin ED, Humphreys DH, Ruiz-Razura A. Nipple reconstruction: The S flap. Plast Reconstr Surg 1988;81:783-7.

11. Kroll SS, Hamilton S. Nipple reconstruction with the doubleoppposing-tab flap. Plast Reconstr Surg 1989;84:520-5.

12. Kroll SS, Reece GP, Miller MJ, et al. Comparison of nipple projection with the modified double-opposing tab and star flaps. Plast Reconstr Surg 1997;99:1602-5.

13. Anton LE, Hartrampf CR. Nipple reconstruction with local flaps: Star and wrap flaps. Perspect Plast Surg 1991;5:67-78.

14. Banducci DR, Le TK, Hughes KC. Long-term follow-up of a modified Anton-Hartrampf nipple reconstruction. Ann Plast Surg 1999;43:467-70.

15. Hallock GG, Altobelli JA. Cylindrical nipple reconstruction using an H flap. Ann Plast Surg 1993;30:23-6.

16. Eng J. Bell flap nipple reconstruction - a new wrinkle. Ann Plast Surg 1996;36:485-8.

17. Losken GM, Bostwick J III. Nipple reconstruction using the C-V flap technique: A long-term evaluation. Plast Reconstr Surg 2001;108:361-9.
18. Rubino CLD, Posadinu A. A modified technique for nipple reconstruction: The "arrow flap." Br J Plast Surg 2003;56:247-51.

19. Eo SK, Da Lio AL. Nipple reconstruction with a C-V flap using dermofat graft. Ann Plast Surg 2007;58:137-40.

20. Hamori CA, LaRossa D. The top hat flap: For one stage reconstruction of a prominent nipple. Aesthetic Plast Surg 1998;22:142-4.

21. Schoeller HS, Puelzl P, Wechselberger G. Nipple reconstruction using a modified arrow flap technique. The Breast 2006;15:762-8.

22. Schwager RG, Smith JW, Gray GF, et al. Inversion of the human female nipple, with a simple method of treatment. Plast Reconstr Surg 1974;54:564-9.

23. Pribaz JJ, Pousti T. Correction of recurrent nipple inversion with cartilage graft. Ann Plast Surg 1998;40:14-27.

24. Brent B, Bostwick J. Nipple-areolar reconstruction with auricular tissues. Plast Reconstr Surg 1977;60:353.

25. Garramone CE, Lam B. Use of Alloderm in primary nipple reconstruction to improve long-term nipple projection. Plast Reconstr Surg 2007;119:1663-8. 